\title{
AN ASSESSMENT OF THE AESTHETIC VALUE OF THE ISLAMIC UNIVERSITY MOSQUE IN CONSTANTINE
}

Received February 28th 2018 | Accepted June 6th 2018 | Available online June 30th 2019 |

DOI http://dx. doi. org/10.18860/jia.v5i3.4622

\section{Said Bousmaha \\ Laboratory EAP/IAU \\ IAU/ University of Blida 1. \\ Algeria \\ bousmahasaid@gmail.com}

\section{Samia Chergui}

Laboratory ETAP/IAU-

IAU/ University of Blida 1 ,

Algeria

cherguisamia@univ-blida.dz

\section{Mustapha Cheikh Zouaoui}

Laboratory ETAP/IAU-

University of Blida 1.

Algeria

czmustapha@yahoo.fr

\begin{abstract}
Contemporary architecture increasingly stands out as a new area of cultura heritage. The "religious patrimony of the future" is one of the principal components which fits naturally into the logical process of preservation and transfer, of the architectural heritage from one generation to the other. The patrimonial process represents the only way to identify and evaluate these "prominent qualities", through different methods of evaluation. this study aims to assess the aesthetic value, considered as one of the essential characteristics of the university mosque in Constantine. It also aims to trigger its heritage process. The methodology was for quantitative and qualitative analysis (quaternaries and formal investigation). The analysis of its outward composition and overall form fits not only into a specific theoretical framework related to the philosophy of art and the subjectivity of beauty perception but depends more on an "in situ" investigation. The evaluation criteria adopted for this study focuses on the values of balance, dominance, unity and variety as well as the parameters of rhythm, proportion and perfect angles. The finding of this study reveals that these criteria made evident different constructive logics used at this university mosque such as the use of Doric proportions and privileged angles, which could serve as an objective argument in according aesthetic value to this mosque in Constantine and prepare its patrimonial future as a religious heritage for future generations.
\end{abstract}

\section{KEYWORDS:}

Patrimony of the future; mosque-university; Constantine; aesthetic; assessment

\section{INTRODUCTION}

Today, recognition of a new patrimony rests principally on the so-called patrimonial values which can be attributed to an edifice. Aesthetic value is the quality most cited to justify the argument for the choice and selection of architectural heritage throughout the patrimonial process.

The present work is a research study which addresses a new approach to the question of patrimony; one that focuses on the preparation of heritage sites, especially those of a religious nature, for future generations. In Algeria, this interest leans more towards the new magnificent mosques, or pole mosques, which show essential qualities or values, like those found at the Emir Abdelkader Islamic mosqueuniversity in Constantine. The choice of this contemporary mosque has been justified by the results of a subjective opinion poll, obtained from a questionnaire distributed to its users.

All the people questioned agreed unanimously on the aesthetic value of the Emir Abdelkader mosque. So that the argument, to class the edifice as patrimony for future generations, could be discussed consistently and scientifically, and for its aesthetic value to be deemed objective, a unanimous opinion was essential.
Moreover, an in-depth evaluation, based on several criteria, was necessary to determine the constructive logic used, which could answer the question as to whether a simple objective appreciation of the aesthetic value of the edifice was enough to grant the Emir Abdelkader Islamic mosque-university in Constantine patrimonial status. This study aims to assess the aesthetic value, considered as one of the essential characteristics of the university mosque in Constantine. It also aims to trigger its heritage process.

\section{METHODS}

To answer the question of objective judgment of the aesthetic value of the mosque-university of Constantine, several logical steps were taken, based on the rules and principles of formal aesthetics [1][2][3][4][5]. The analysis of the exterior components of this mosque first required an extensive collection of metric data of acceptable accuracy. In this sense, a measurement campaign using a "digital laser range finder" made it possible to update the records of the various plans, elevations and constructive details of the building. The field investigations were supplemented by an iconographic study to possibly distinguish the dissimi- 


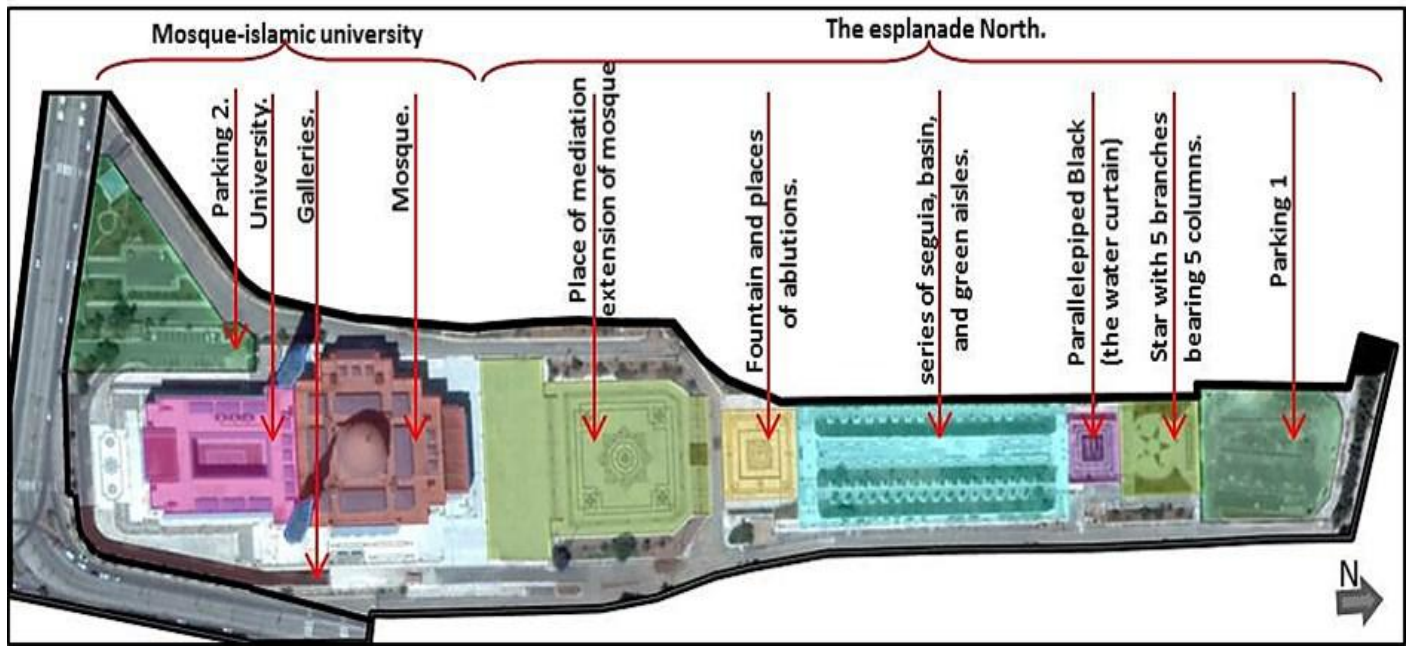

Figure 1. Mass Plan of Islamic mosque-university of Constantine, Algeria [source: Authors]

larities between the original graphics documents of the mosque-university and the image it refers to today. Formal analysis began to identify, on its overall form and its secondary elements, the apparent principles of visual composition, measurable directly by visual perception, which is associated with unity, variety, balance and rhythm. Finally, this formal analysis was devolved to discovering the hidden architectural aesthetics settings, which indirectly influence the exterior composition of the building that includes the scale, proportions and privileged angles. Moreover, the patrimonial process proposed, in a second stage, for the mosqueuniversity of Constantine, is primarily based on the determination of its heritage values, which are defined as "a set of characteristics, or of positively quality perceived by certain individuals or groups of individuals" [6]. The starting point for determining these values is an individual pre-judgment that takes into account in situ observations and theoretical concepts. [7], [8]. Based on the results of the first phase that reveal the positive values of the mosque-University Islamic of Constantine and to find somehow the collective judgement, we chose to go to a questionnaire survey to confirm or deny our observations on the one hand, and to see the principal heritage value, on the other. The proposed questionnaire is intended for 60 users of the Mosque-University of Constantine, including visitors and tourists. The closed items were preferred because they give more natural treatment and the fact that they were enriched with semi-open questions, allow respondents to explain their answers.

The twenty-seven questions are structured into two broad groups: the first includes questions about social determinants such as age, gender, and status. The second category of items is related to the subject's attitudes towards the values they attribute to the mosque-university at Constantine itself.

\section{DISCUSSION}

\section{PRESENTATION OF THE OBJECT OF STUDY}

The idea for the project of the Emir Abdelkader mosque-university came from Constantine dignitaries who cited the absence of a significant religious building, able to fulfil the growing needs of the faithful. In 1968 , therefore, they envisaged the construction of a new mosque with the capacity to hold 10,000 worshippers. A limited budget pushed the founders to ask the young Algerian state for financial aid. The late president Houari Boumedienne was much interested in the project and wanted the mosque to reflect the identity and principal religion of independent Algeria.

Architectural and technical studies were officially entrusted to the engineering consulting firm SONATRACH in 1969. A multidisciplinary team was immediately set up under the direction of the Egyptian architect, specialised in Islamic architecture, Hossein Bakri, who, with the presidential consulting architect, Mustapha MOUSSA, signed all the plans and architectural details of the mosque. In 1984, the first part of the project comprising the Islamic university was finished while work continued on the mosque until 1994, when the project was finally completed [9].

The mosque-university at Constantine covers an area of $12,600 \mathrm{~m} 2$ and can hold 12000 worshippers. The principal building material is reinforced concrete, decorated with artificial stone and marble[10].

This mosque has two twin minarets, each measuring $110 \mathrm{~m}$ high, and a cupola, $65 \mathrm{~m}$ high. The cruciform plan, with a cupola over the middle of the square space, as well as the size and function of this building of teaching and worshipping, clearly resembles the college mosque of Sultan Hassan in Cairo, founded in 1356 by the Mamlouka sultans [11].

The central part of the cruciform plan, where the arms of the cross converge, holds the main prayer room. It is square in shape and has nine naves, running parallel to the qibla wall, with nine others perpendicular to it. A cupola, with double-sided pendentives, and mounted on a drum, hangs over three of the bays, 


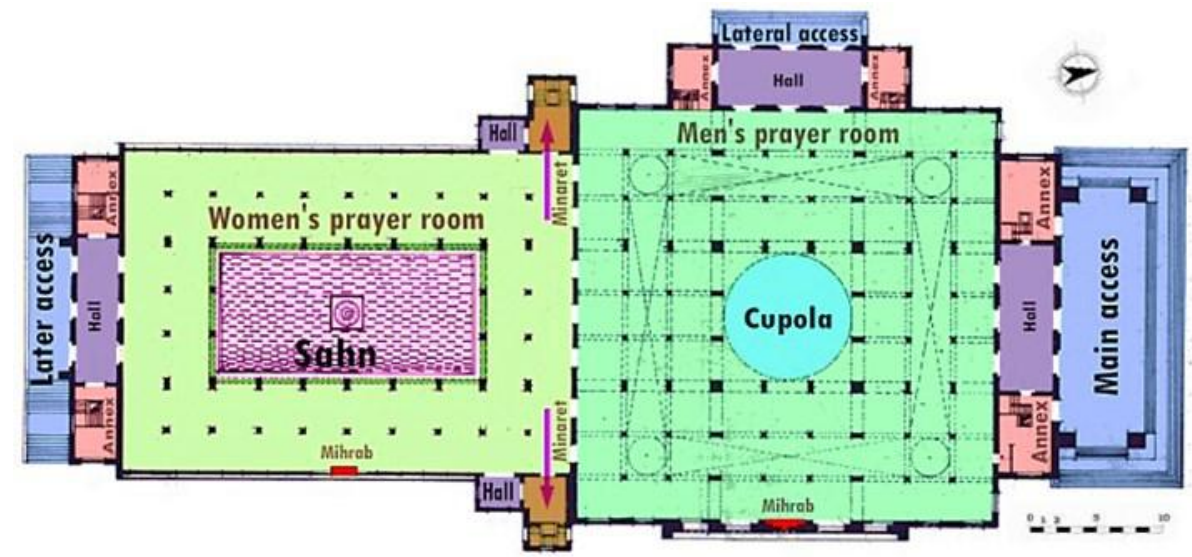

Figure 2. The plan of the ground floor of mosque-Islamic University of Constantine, Algeria [source : Authors]

while four other domes, covered on the outside with blue tiles, stretch over the intersection of the second and eighth nave. The latter also has four raised vaults covered with blue tiles. The cupola, domes and vaults allow light to penetrate the square prayer room, thanks to the lateral openings in each of the elements.

The arms of the cruciform plan are composed of:

- in the south, by another prayer room, adjacent to the square room but separated from it, by a wall, pierced with seven doors. It is rectangular in shape and is built around a patio with ten other naves running perpendicular to the qibla wall. Width ways, it extends further back than the square room and has bays on each end. This part is currently reserved for women and has independent access.

- in the north, by the courtyard and the main entrance hall, as well as offices and administration wings.

- in the west, by the side entrance hall, opposite the mihrab, above which can be found a prayer room, reserved for women, but which has been converted into a library and, communicates with the main office using a balcony, protected by a sort of moucharabich (wooden screen).

- In the east, the arm of the cruciform plan has been cut off by the mihrab wall and has, on the outside, a projection embellished with five arcades[12].

\section{RESULTS}

Among the sixty (60) respondents in this first phase of the survey, which is still underway, fifty-two (52) responded positively to the question about the value of the architectural aesthetics of the university mosque. It is, therefore, an absolute positive consensus that confirms our hypothesis about the architectural beauty of the study building. Nevertheless, our analysis is necessary to objectively confirm or deny the aesthetics of the outward composition of the mosque studied. Our analysis is based on all the constructive parameters which affect the aesthetics of the overall form of the building. The following points summarise the steps of our diagnostic study, which was carried out on two levels: firstly, an evaluation of the overall form of the edifice, followed by an analysis of the secondary elements, simultaneously applying the same analytical principles of balance, dominance, unity and variety, as well as the parameters of rhythm, proportion and perfect angles.

\section{ANALYSIS OF THE OVERALL OUTWARD FORM UNITY AND VARIETY}

The constructive parameters are the qualities obtained when all the elements have been set out and arranged logically and agreeably, and in such a way, that none of them competes for a position of dominance [13]. The unity of the outward composition of the Emir Abdelkader Islamic mosque-university in Constantine can be expressed through the following elements:

- the northern part of the edifice, which comprises both the university and the women's prayer room, surrounded by a patio, has a regular rectangular form except a few protrusions in the form of the minarets and the secondary entrance to the mosque.

- the main prayer room represents the centre of interest of the mosque and has a regular square shape, except for a few irregularities where porches were built over entrance doors.

- despite the need to give importance to the main prayer room through its way, as well as the protruding irregularities of both the other prayer rooms, in the form of the twin minarets and the main and side entrances, the overall configuration of the mosque, after reconstruction, is one of a partial regularity, of rectangular shape.

- the roof is horizontal in form and is on two levels: the first and highest, is that of the main prayer room; the second is that of the university and the women's prayer room.

- on the eastern and western facades, at the Islamic University and women's prayer room, a static unity, 
brought about by repeated and regular use of arches, gives the impression of stability of form.

- a dynamic integration of the overall structure is achieved by a relative inclination in two directions, sloping more towards the southern esplanade than towards the north.

\section{THE CONTRAST}

If Bruno ZEVI is to be believed, then, the unity of a project results instead in a synthesis of contrasting elements than in rigorous equality, and if an edifice is to "live", it is necessary that its vitality is expressed by a contrast[14]. This can be easily seen in the outward composition of the Emir Abdelkader Islamic mosqueuniversity in Constantine through:

- the opposition between the vertical plane of the two twin minarets, with square bases $110 \mathrm{~m}$ high, and the double-hulled cupola, mounted on a drum $65 \mathrm{~m}$ high, and the horizontal plane of the rest of the edifice.

- the contrast between the curved form of the arches on the different facades and the flat shape of the roof.

A harmonious contrast can be seen through the colours and contrasting textures of the materials used, which influence the richness and aesthetic perception of the building and can be summarised as follows:

- the contrast between the low saturation, light yellow colour of the artificial stone and the blue of the tiles and the wooden doors and windows.

- the opposition in the treatment and texture of the facades, which varies from the simplicity of the exterior wall faces, to a wealth of detail in the apertures, taking the form of arabesque screens, decorated arches, ledges and ornate bands.

\section{THE DOMINANCE}

When Zevi addressed the question of dominance, he gave the following description: "In every composition, a centre of interest is necessary, a sort of focal point that catches the eye." [14]. According to Sven Hesselgren, we can attract attention towards an object through several visual means, including monumentality, which is better appreciated than a minuscule object [15]. In our university mosque, dominance is expressed by the imposing mass of the cupola and the height of the two minarets, which make of this composition, a centre of interest in the overall outward structure. The same goes for the openings, which are longer than they are full, and the use of stilted arches. Both express a need to give importance to the dominance of height. The apertures on the different facades of the mosque are dominated by the motifs on the arabesque screens and metal grids, which fill all the openings on the exterior walls. Dominance is portrayed through the texture of the artificial stone used on the facades and by its yellow colour.

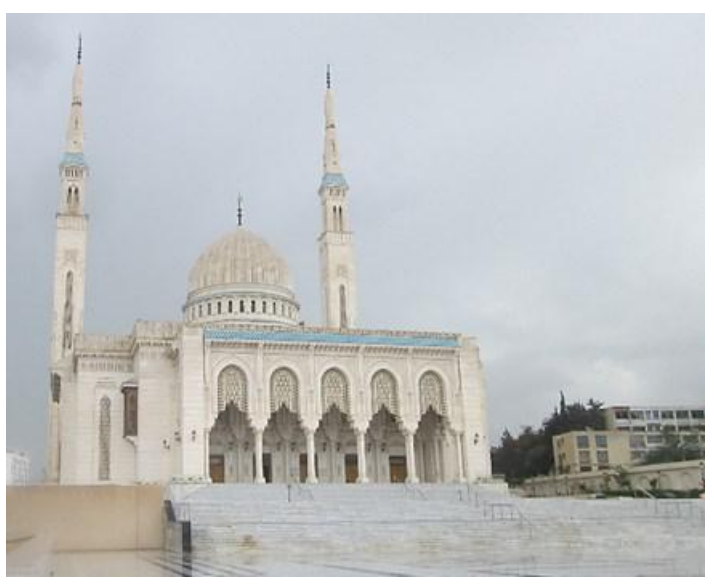

Figure 3. Dominance on the side façade [source: Authors]

\section{THE BALANCE}

According to Arnheim, balance is an indispensable quality in the conception and physical and visual composition. The author defines it thus: "The balance is the state of distribution in which all action has come to a standstill. In a balanced composition all such factors as shape, direction and location are mutually determined in such way that no change seems possible, and the whole assumes the character of "necessity "in all its parts An unbalanced composition looks accidental, transitory, and therefore invalid." [16]

The search for balance in the outward composition of the Emir Abdelkader Islamic mosque-university has shown:

- a natural counterbalance as seen through the dominance of both the height of the two twin minarets and the mass of the cupola, on the one hand, and the horizontal plane of the facades, on the other.

- the balance between the wall faces and the apertures, due to the symmetry between the primary and rear façades, despite a weak deformation caused by the side entrance.

- on the east and west facades, the position of the minarets over the central nave (the tenth nave, running perpendicular to the wall of the qibla, separates one side of each of the nine naves from the other, in each of the prayer rooms as well as in the airlocks ) and in relation to the boundaries of the two prayer rooms, gives a precise balance to the outward composition, which can be appreciated from the facades on the east and west sides, despite the difference in the level of the two rooms and the dominance of the cupola mass.

- the natural balance between the simplicity of the smooth texture of the artificial stones, covering the facades and the richly decorated bands and screens.

- the balance between the horizontal form of the roof and the curved shape of the arches and armatures. 


\section{RHYTHM AND REPETITION}

About rhythm and repetition, Lalitte stated that: "The notion of rhythm, as a property of time and space, equally concerns all art forms, especially architecture. Rhythm, therefore, organises the sequence of lines, shapes, colours, movements..." [17]. It is a quality considered as fundamental in the aesthetic judgement of architectural work. The rhythm in the Emir Abdelkader mosque-university is apparent through the regular use of arches on all four facades of the edifice. This repetition can be classed on three levels, according to the frequency of occurrence; robust, average and weak repeat. Constant repetition is marked by:

- the use of Moorish arcades on the drum of the cupola, totalling thirty-two (32) small arches in number.

- the repetition of the stilted arch, repeated eight times on both the east and west facades, where the university and women's prayer room are situated.

- the repetition of bands and corbels, and its repeated use, as a motif on all the parapets of the mosque.

An average degree of repetition is reflected in:

- the stilted arches, repeated five times (this number symbolises the number of prayers each day in Islam) on the façade of the central entrance porch and once on each of its sides.

Repetition of weak frequency can be seen throughout the exterior composition of the mosque. The repetition of the muqarnas arch, repeated only three times on the side door entrance, is one such example

\section{THE PROPORTIONS}

The proportions in architecture are defined by a harmonious relationship between two or more constructive details, which foster the sentiments of stability, force, security and, above all, aesthetic satisfaction. The following citation clearly illustrates this idea: "The beauty of nature is because every object is provided with an attractive proportion vis-à-vis its surroundings. Beautiful architecture should also evoke such chemical changes in our brain, which stimulate a feeling of pleasure or happiness" [18]

Our analysis of the outward composition of the university mosque revealed several of these harmonious proportions, of which the most remarkable are cited in the following points: between:

The balances approaching perfection, type $(\varphi)$

- the height of a minaret (A1) and the height of the cupola (A2).

- the height of a minaret (A1) and the length of the prayer room (B1).

The dynamic proportion, type $\left(\varphi^{2}\right)$ between the length of the whole mosque, including the staircases, in the rear and main entrances (B2), with the height of the cupola (A2).

The dynamic proportion, type $(\varphi / 2)$ between the height of the women's prayer room (A4) and that of the main prayer room (A3).

The dynamic proportion, type (3): The height of the cupola $\left(A_{2}\right)$ is almost three times the height of the principal prayer room (A3).

The dynamic proportion, type $(\sqrt{ } 2)$ between the height of the main prayer room ( $\left.\mathrm{A}_{3}\right)$ and the distance between the axis of the cupola and the end of the square prayer room (B3).

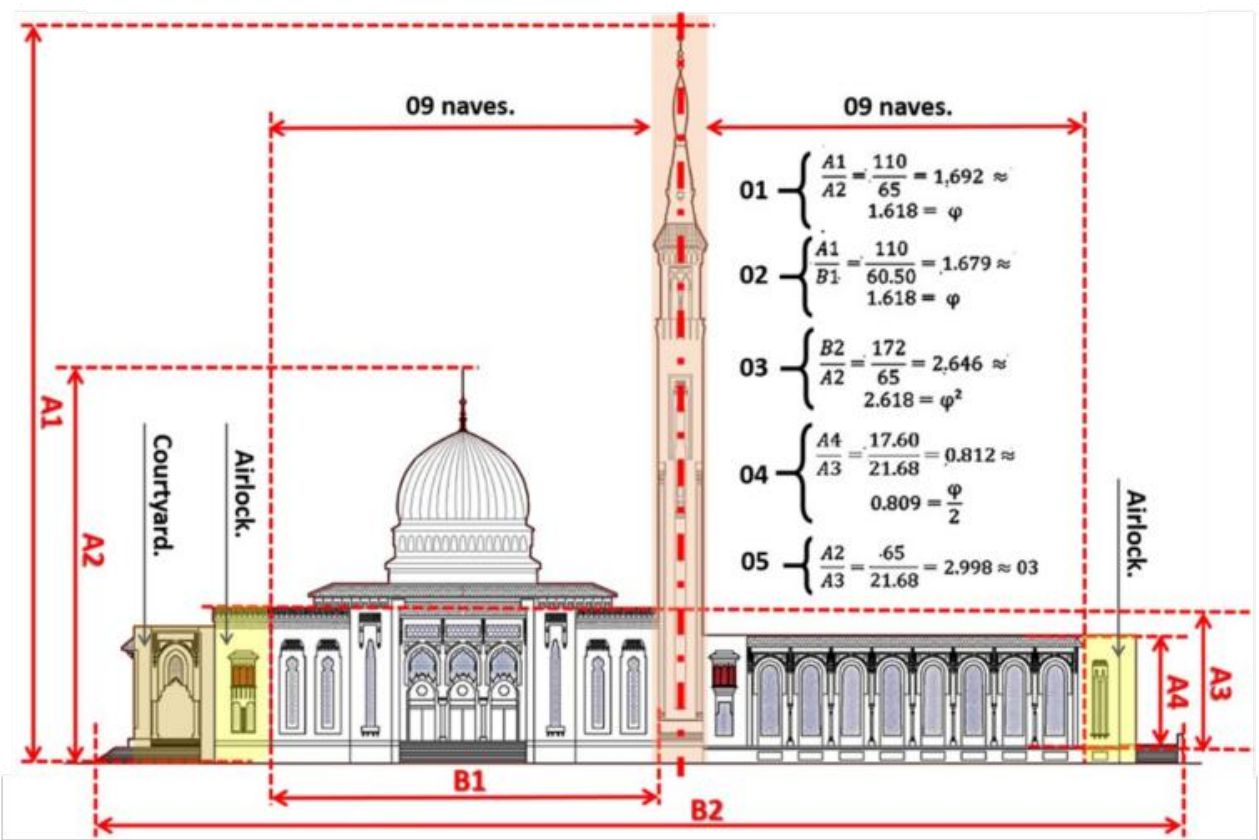

Figure 4. The balance and the proportions in the mosque-Islamic University of Constantine, Algeria [source : Authors] 
$(\varphi)$ :

The rectangle approaching the perfect type

- a rectangle of almost perfect proportions can be seen at the main entrance since its length is equal to that of the distance between the five arches (B4) and its width is delineated by the highest point of the tiled protrusion on the entrance porch and the level of the Esplanade ( $\mathrm{A} 5$ ).

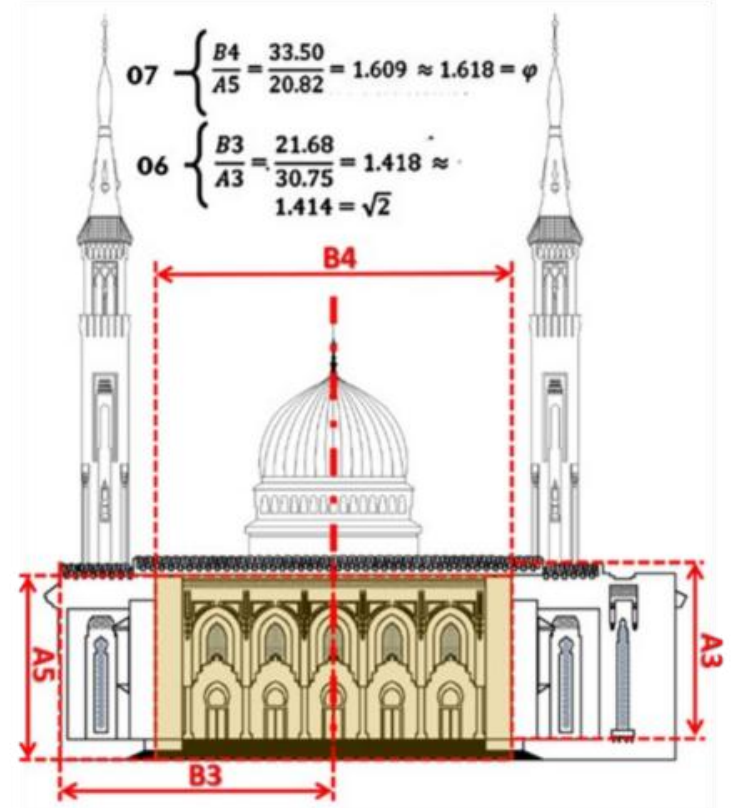

Figure 5. The proportions of the main facade of the MosqueUniversity of Constantine [source: Authors].

- the length of the entrance hall (B5) and the height of the side entrance, including the parapet on the terrace (A6), form another rectangle approaching the perfect type $(\varphi)$.

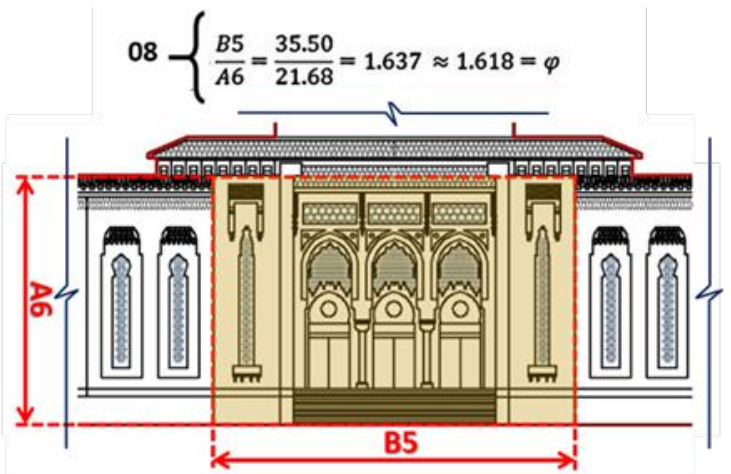

Figure 6. Gold rectangle at the side access [source: Authors].

The dynamic rectangle, model $(\sqrt{ } 2)$ : at the rear entrance, the relation between the length of the door frame and its height, delineated by the bottom level of the tiled protrusion and the entrance floor, forms a dynamic rectangle of the type $(\sqrt{ } 2)$.

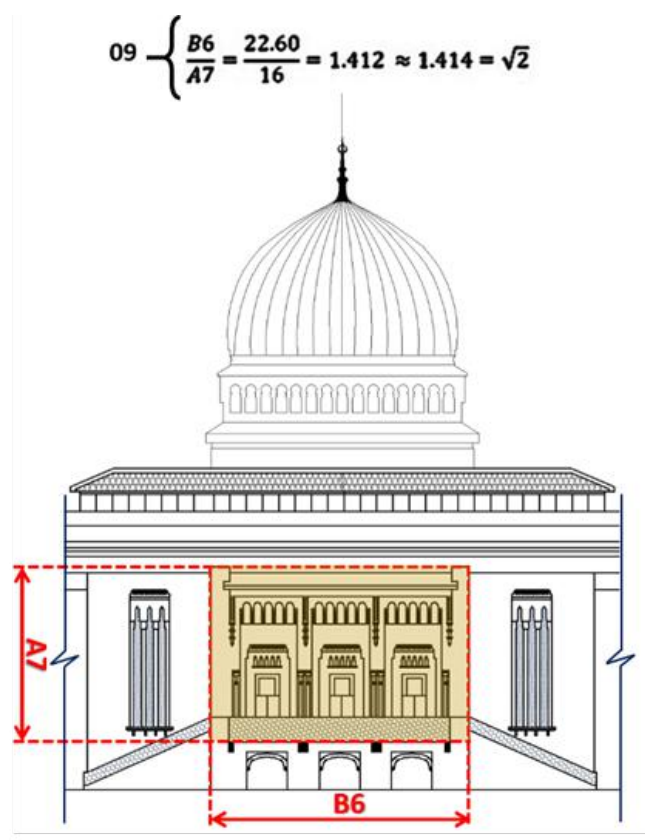

Figure 7. Dynamic rectangle type $(\sqrt{2})$ in the posterior access [source: Authors].

\section{PERFECT ANGLES}

Perfect angles, in conjunction with other geometric forms (perfect rectangles...), seem to constitute a unique framework suited to the sensations of calm and balance. Numerous monuments of ancient art testify to the use of these geometric forms to capture these sensations [19].

Since the beginning of time, perfect angles have always been considered as a factor for harmony, and an indispensable criterion in the perception of architectural beauty.

Our analyses of the angles, in the Emir Abdelkader Islamic mosque-university in Constantine, have shown the presence of several perfect aspects, with differing measurements, which can be exemplified through:

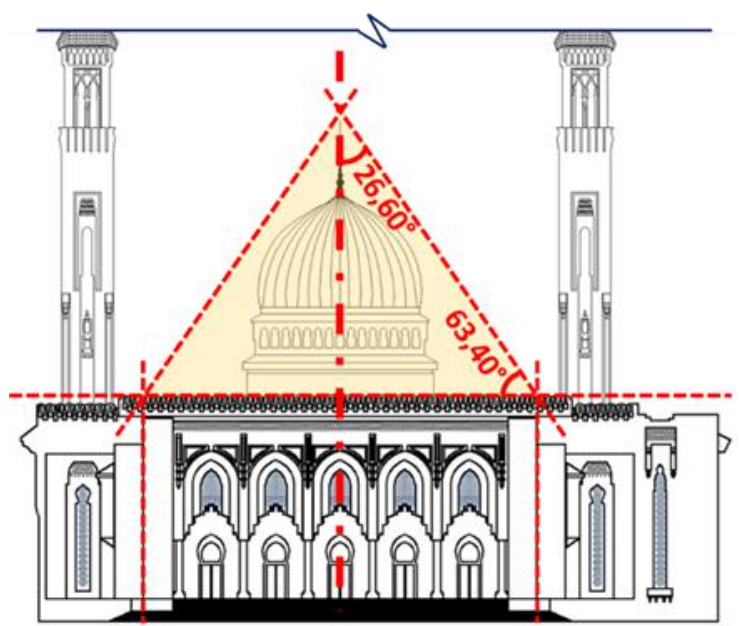

Figure 8. Examples of perfect angles on the main façade [source: Authors] 


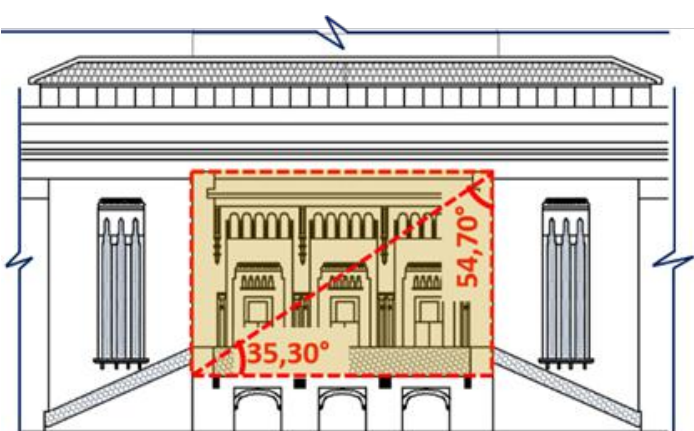

Figure 9. Examples of perfect angles on posterior access [source: Authors]

\section{ANALYSIS OF THE SECONDARY ELEMENTS}

The mosque at the Emir Abdelkader Islamic University, in Constantine, shows a wealth of aesthetic detail in its secondary elements which, besides playing an essential role in the visible perception of its outward composition, are, in themselves, independent elements. In the section that follows, we will try to analyse the aesthetic values of the secondary aspects of the Emir Abdelkader mosque:

\section{THE ENTRANCE HALLS}

There are three entrances to the Emir Abdelkader university mosque in Constantine: one main one leading to the men's prayer room, facing north; a second, subsidiary one, facing south; and a third side entrance to the west; leading to the library on the first floor, as well as the principal prayer room.

The main entrance is composed of two blocks, where the yard and the administration wings of the mosque are found. A portico, it is supported by 22 cylindrical columns, superimposed on a raised base of 19 steps, of which seven lead from the esplanade to the landing, with the other 12, going to the yard. From here, access to the men's prayer room is gained by three central doors, made from wood and sculpted copper. Two other side doors lead to the offices and the administration wings.

The principal façade of the entrance porch, which measures $38.30 \mathrm{~m}$ long, comprises a series of 12 cylindrical, twin columns, with corner scrolls of Zianidecomposite, on their pedestals and capitals. These twin columns support five units of stilted arches, sustained by decorated corbels, which, along with five screen panels, make up the false arches of the pelmets. Above them, a ledge, held by corbels and covered with blue tiles, links the arches of this central doorway together.

On the east and west facades, a unit of stilted arches, identical to that of the main facade, can be seen. A wooden q'bou (corbelled space gained on the street), supported by corbels and covered with tiles, can be found at the level of the first floor, below which two stilted arch windows, protected by metallic grills, can be seen.

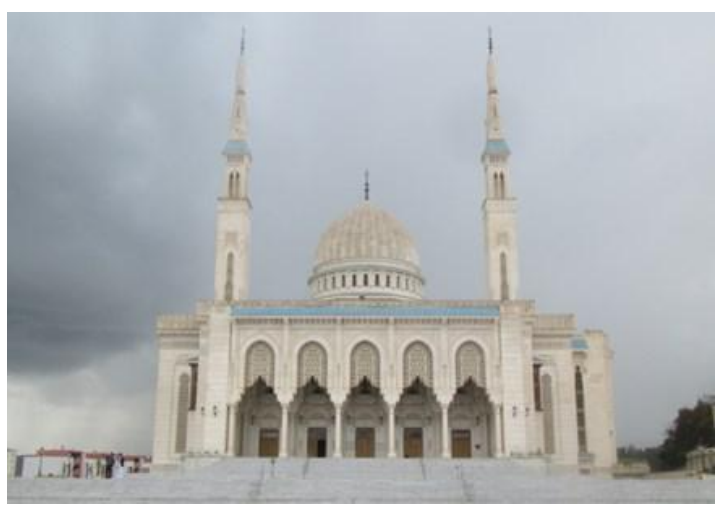

Figure 10. View of the main facade of the Mosque-university of Constantine [source: Authors]

The south-facing, secondary access is situated above the university entrance and is accessible by two flights of stairs. On this entrance façade, a central framework is composed of three units: each has a door made from wood and bronze, a muqarnas, calligraphic picture, two columns, five Moorish arches and five stilted arches. The three units are linked on top by a ledge, supported by corbels. On either side of the central framework, three more openings with stilted arches can be found together, overhanging a window, sustained by four corbels, and whose glass is protected by a metallic grill.

The subsidiary side entrance is situated on the west side of the great square room. Elevated seven steps above ground level, it is composed of three units, embedded in a central framework, and built on a high projection, sustained by corbels and covered in blue tiles. Each group consists of both a wood and copper door, taking the form of a polylobate arch, whose centre is pierced by a circular glass opening, decorated with a geometrical flower motif, and a pointed stilted arch, filled with a screen, and adorned, inside, with a second plaster arch, forming a kind of pelmet-like structure, as well as a rectangular opening, protected by filters.

On each side of these units, towards the back and on another plane of the façade, two large openings, covered by a metallic grill, can be seen, the tops of which are marked by a tiled projection, sustained by two corbels.

Examination of the entrances revealed the following points:

- The doors to the mosque possess a formal balance, expressed by a perfect symmetry about its central axis. We can also see a dynamic unity throughout the rectangular framework of the three entrances.

- Contrast appears principally through the use of different natural materials, such as artificial stone, tile and wood, which also explains the difference of colours. We can also see a contrast between the simplicity in treatment on the outside wall faces and the decoration on the arches and capitals; and between the horizontality of the rectangular 
framework and the verticality of the stilted arches, as well as between the straight and curved forms.

- the three doorways reinforce the dominance of the dome, on the one hand, and the yellow colour, on the other.

- we also notices a repetitive rhythm at each of the entrances. While the repetition of bands and corbels is active at all three of them, the repetition of arches and doors is average at the main entrance hall. On the side entrance, we can see a rhythm of weak cadence through a triple repetition of the arch and the door. As for the rear access, rhythm is strongly marked in the repetition of the armatures and the corbels with a weak cadence in the repetition of the doors.

\section{THE MINARETS}

The Emir Abdelkader mosque consists of two twin minarets with square bases, made from reinforced concrete and covered with artificial stone (a mixture of powdered marble and white cement). They are situated at the two corners of the rear wall that runs between the square prayer room and the university. Both minarets stretch to a height of $110 \mathrm{~m}$. Each is composed of three towers, accessible by a staircase and a lift.

- the first tower is built on a bay, $6.70 m$ square. It consists of a rectangular frame, decorated at the top by Muqarnas motifs, and slender columns highlight its corners. All its wall faces have screen panels with diamond lattices and furnished balconies. It is edged, at the top, by 20 ordinary merlons and four corner merlons, all rectangular in shape, with a sort of ledge at the top, which acts as a safety rail.

- The second tower, of parallel epipedic form, with a square base and truncated at its four corners, is built on top of the first. It has two arcatures of polyloulate arches and six small high openings on each of its facades. Twenty-eight corbels support the sloping ledges covered in blue tiles.

- the third tower is the most upper part of the minaret. It is cone-shaped and has four triangular openings with simple screens and raised ledges. Four octagonal motifs are painted below the shelves. This tower is mounted on an ellipsoidal mass on which a final is fixed, composed of three differentsized copper balls and a crescent, indicating the direction of the qibla.

Besides participating in the overall outward composition of the edifice, the two minarets exhibit:

- formal balance seen, not only in the axial symmetry and the homogeneity in colour of the artificial stones that cover the two minarets but also in the rectangular frames of their screen panels with diamond lattices. These give the two towers a dynamic unity.
- the dominance of the vertical plane, culminating in pointed extremities.

- contrast is evident between the flat, smooth surfaces of the outside walls and the rough, complexity of the decorative bands, as well as the arabesque screens which fill the spaces in the minaret's structure. We can also see a weak contrast between the nature and colour of the materials used: artificial stone, on the one hand, and tile, on the other.

- rhythm is clearly visible through the repetition of the following elements: three decorated balconies in the lower parts of the minarets and four in the middle; the columns which highlight the four corners of the two towers; the decorative panels with their arabesque screens on all the four facades, the arcatures of the lanterns which are repeated in both units in each façade; and by other elements including the corbels, the bands and the parapets.

\section{THE DOME}

The Emir Abdelkader Islamic university mosque in Constantine is dominated by a gigantic cupola, on pendentives, supported by a drum, which resembles that of the Kairouan mosque in Tunisia [20]. It is double-sided and is built of reinforced concrete, covered in artificial stone. Structurally, the dome sits on four pendentives which hang from a cylindrical crown, $18.70 \mathrm{~m}$ in diameter and pierced with 32 openings in the form of Moorish arcatures. The main body of the base contains ten other opportunities, between the pendentives, on each of its sides. These are surmounted by curvilineal, polylobate arches and are embedded in rectangular alcoves, grouped and following the rhythm 02 then 06 in the middle, arranged 03 over 03 , then 02.

The dome of the Emir Abdelkader pole mosque covers the three central bays of the square prayer room, at the height of $65 \mathrm{~m}$. However, the transition from the base to the dome is marked by two protruding ledges, covered in blue tiles of two different shapes: decagonal on the lower circle of the drum, and circular where the fluted body begins. Treatment of the outside texture of the dome has created 12 grooves which converge at the top, where a rod, threaded with two different-sized balls and a crescent, made from copper, point towards the qibla.

Besides its dominance on the overall form of the edifice, as an independent entity, the dome of the mosque possesses many qualities that enhance the visual composition, which can be exemplified by the following points:

- a formal balance is generated by the perfect symmetry of the dome about both the central axis and homogeneity of form, as well as by colour and texture. 
- the overall shape of the dome is dominated by the imposing mass of its base, on the one hand, and the colour of the texture materials, on the other. This reflects specific stability in the outward composition of the dome.

- the pyramidal sloping from the square base to the top of the dome gives it relative dynamism.

- contrast is expressed through the use of two different materials (tile and artificial stone) and between the emptiness of the screened openings and the fullness of the main body; between the horizontality of the rectangular form of the drum and the verticality of the overall structure, ending in a pointed angle at the top; and between the smoothness of the faces of the base and the roughness of texture in the main body of the dome.

- rhythm is also present in this entity through a regular repetition of grooves on the main body of the dome and through the openings on the crown, which are all of identical shape and dimension (the 32 windows on the drum are embedded in alcoves, where each is decorated with a raised moulding in the form of a stilted arch; the whole is topped by two rectangular supports which link the stilted arches). Rhythm is also apparent in the repetition of the pendentives as well as the openings on the base of the cupola.

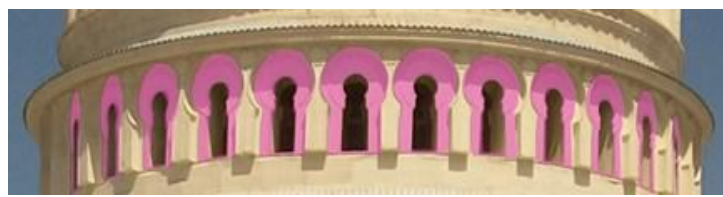

Figure 11. The repetitive rhythm of the arches of the drum of the dome [source: Authors]

\section{THE SYNTHESIS}

Analysis of the outward composition of the Emir Abdelkader Islamic university mosque in Constantine revealed an aesthetic richness on the outside shell of the structure, which has been addressed on two levels:

The first analytical step was confined to an examination of the overall form of the edifice, which showed that its aesthetic richness stands out from the unity as a whole. Similarly, it illustrated that variety is reflected in the diversity between the static and the dynamic units used. This result in a partial regularity of the overall form, which is reinforced by the dominance of texture and colour, as well as the verticality of the two minarets and the imposing mass of the cupola. Moreover, a study of Contrast on the overall form confirmed its aesthetic richness. It can be seen at several levels and includes the opposition between verticality and horizontality; between both the pointed and curved shapes and the straight lines; as well as between the simplicity of the wall faces and the wealth of decoration on the screened openings and other elements

Regarding the balance of the over form, an informal type can be seen between the height of the two minarets and the mass of the cupola, on the one hand, and the horizontal plane of the facades, on the other. Another balance is reflected in the central and rear facades, between the fullness of the wall faces and the emptiness of the apertures brought about because of their symmetry. Moreover, the central position of the minarets, on the east and west facades, give a sort of balance to the outward composition.

The harmonious repetition of several elements, such as the arcatures and the arches on the different facades as well as the proportions and the use of perfect angles, further reinforces the richness of the overall outward form of the Emir Abdelkader mosque in Constantine.

The second level of the evaluation was dedicated to the secondary elements of the outward composition. Each component of the overall form of the edifice was examined independently, which allowed for a consolidation of the results obtained in the first step of the study. The aesthetic value of the architectonic components of the pole mosque in Constantine is incontestable. It is easily seen throughout the rich detail of the twin minarets and the cupola, and on the three entrance halls of the edifice. The use of rhythmic treatment, balance, Contrast and unity in each element reflects the application profoundly sought in a detailed aesthetic.

Table 1. Recapitulation of the external composition analysis results of the mosque- university Islamic of Constantine [source: Authors]

\begin{tabular}{lll}
\hline Values & Used & Example Of Location \\
\hline Unity and variety & Yes & The overall shape \\
The balance & Yes & Facades \\
Rhythm and Repetition & Yes & Moorish arcades \\
Proportions & Yes & The height of minaret \\
& & vs the height of the \\
& & cupola \\
Perfect angles & Yes & Posterior access \\
\hline
\end{tabular}

\section{CONCLUSION}

After evaluating the aesthetics of the exterior composition of the Islamic mosque-university Emir Abdelkader of Constantine, regarding either the global form or the secondary elements, it appears that the two categories of direct and indirect parameters, which act on the perception of the architectural aesthetics, are distinguished on the study building. Thus, it is possible to say that measurable parameters directly by the visual understanding like the unity, the variety, the balance and the rhythm as well as the hidden prin- 
ciples of the aesthetics that indirectly influence the external composition of the building in term of the scale, proportions and privileged angles, are positively highlighted.

Results obtained objectively affirm the collective judgment of the surveyed users and join their views on the beauty and aesthetics of the mosqueUniversity. This encourages us to initiate new levels of research and apply other more in-depth assessments such as assessing the aesthetics of the building on a macro scale to determine the rate of its integration into the city's urban landscape. However, it is worth mentioning the need to address the authenticity and identity of architectural elements used and compare them with new aesthetics components of heritage in modern architecture.

Moreover, this research work represents only one step in the process of "patrimonialization" of the mosque-university of Constantine which aims to justify its upcoming heritage and prepare the future of contemporary religious architecture in Algeria as the spiritual heritage of future generations.

\section{REFERENCES}

[1] J.-F. Dortier, "Holisme contre élémentarisme," Sci. Hum., $n^{\circ}$ Hors-série $n^{\circ} 7$, p. 45, Oct. 2008.

[2] P.-A. Johnson, The Theory of Architecture, Concepts Themes \& Practices. New York: Wiley, $1^{\text {st }}$ edition, p. 402, 1994.

[3] A. Ismail, Les principes esthétiques dans la critique, Présentation, interprétation et comparaison. Bagdad: A.C.G., p. 113, 1986.

[4] J. Stolnitz, Aesthetics and philosophy of art criticism, a critical introduction. Houghton: Mifflin, $1^{\text {st }}$ edition, pp. 633-634, 1960.

[5] I. Benarbia, L'évaluation de la valeur esthétique des monuments historiques: cas de la grande mosquée de Nedroma. Post-graduate thesis, Algeria: University of Tlemcen, pp. 63-65, 2012.

[6] M. de la Torre and R. Mason, "Assessing the Values of Cultural Heritage," The Getty Conservation Institute, Los Angeles: Research Report, pp. 3-4, 2002.

[7] A. Riegl, Le Culte moderne des monuments. Son essence et sa genèse. Paris: Le Seuil, Édition revue et augmentée, p. 88, 2013.

[8] S. Chergui, Les Mosquées d'Alger. Construire, gérer et conserver (XVI ${ }^{e}-X I X^{e}$ siècles). Paris: $\mathrm{PU}$ Paris-Sorbonne, pp. 185-186, 2011.

[9] T. Redjel, La mosquée Emir Abdelkader: un édifice ... une renaissance. Constantine: ARAJA Edition, p.25, 2015.

[10] Y. Li and S. Ren, Building decorative materials. Oxford: Woodhead Publ, p. 41, 2011

[11] K. Ismail, "Sultan Hassan mosque: an Islamic architectural wonder analytical study of design and its effect on Islamic Cairo," J. Islam. Archit., vol. 94-105, p. 97, 2010.

[12] B. Belabed-Sahraoui, "L'architecture de la Mosquée-université Emir Abdelkader," Architecture Islamique, Algeria: University of Constantine, pp. 1-13, 2016.

[13] M. Q. de Quincy, Dictionnaire historique d'architecture. Paris: Librairie d'Adrien le Clere, pp. $645-646,1832$

[14] B. Zevi, Apprendre à voir l'architecture. Paris: Editions de Minuit, p. 113, 1959.

[15] S. Hesselgren, The language of architecture. Lund: Studentlitterar, $2^{\text {nd }}$ edition, p. 215, 1969.

[16] R. Arnheim, Art and Visual Perception: A Psychology of the Creative Eye. California: U.C. Press, p. 20, 2004.

[17] P. Lalitte, "Le rythme,", Actes des secondes Rencontres inter artistiques, Paris, vol. série: Conférences et séminaires, n² 24, p. 118, 2005.

[18] A. Sharma, R. Singh, and P. S. Chani, "Proportions and Architecture," Social Science Research Network, Rochester, New York, pp. 44-45, 2012.

[19] L. E. Michel and J.-P. Mathieu, "Le design de la grande pyramide de Chéops: un modèle de proportions et d'angles d'or (ou privilégiés)," RHPM, p. 77, 2015.

[20] S. S. Blair and J. M. Bloom, The Art and Architecture of Islam, 1250-1800. New Haven: Yale University Press, Reprint edition, 1996. 